\title{
Synthesis of Three Stereoisomers of $p$-tert-Butylthiacalix[4]arene Substituted with (Ethoxycarbonyl)methoxy and Fluorescent 1-Amidoanthraquinone Fragments
}

\author{
Alena A. Vavilova, Roman V. Nosov, Olga A. Mostovaya, and Ivan I. Stoikov@ \\ Kazan Federal University, A.M. Butlerov Chemical Institute, 420008 Kazan, Russian Federation \\ ${ }^{\circledR}$ Corresponding authorE-mail: ivan.stoikov@mail.ru
}

\begin{abstract}
New tetrasubstituted at the lower rim thiacalix[4]arenes containing both (ethoxycarbonyl)methoxy and 1-amidoanthraquinone fragments in three conformations: cone, partial cone and 1,3-alternate were synthesized. It was shown that depending on the alkali metal cation (sodium, potassium or cesium) in the alkylation of the diester based on p-tert-butylthiacalix[4]arene by 2-bromo-N-(9',10'-dioxo-9',10'-dihydroanthracene-1 '-yl)acetamide template effect of metal cation was observed. The fluorescent properties of the obtained compounds were studied.
\end{abstract}

Keywords: Thiacalix[4]arene, synthesis, template effect, fluorescence spectroscopy.

\section{Синтез трех стереоизомеров $n$-треm-бутилтиакаликс[4]арена, замещенных (этоксикарбонил)метоксильными и флуоресцентными 1-амидоантрахиноновыми фрагментами}

\author{
А. А. Вавилова, Р. В. Носов, О. А. Мостовая, И. И. Стойков ${ }^{\circledR}$ \\ Казанский федеральньгй университет, Химический институт им. А.М. Бутлерова, 420008 Казань, Россия \\ ${ }^{\circledR}$ E-mail: ivan.stoikov@mail.ru
}

\begin{abstract}
Синтезированы новые тетразамещзенные по нижнему ободу тиакаликс[4]арены, содержащие одновременно (этоксикарбонил)метоксильные и 1-амидоантрахиноновые фрагменты в трех конфигурациях: конус, частичный конус и 1,3-альтернат. Показано, что в зависимости от используемого катиона щелочного металла (карбонат натрия, калия или цуезия) в реакции алкилирования диэфира на основе n-трет-бутилтиакаликс[4] арена 2-бром-N-(9',10'-диоксо-9',10'-дигидроантрачен-1'-ил)ацетамидом наблюдается «темплатный» эффект катиона металла. Изучены флуоресцентные свойства полученных соединений.
\end{abstract}

Ключевые слова: Тиакаликс[4]арены, синтез, «темплатный» эффект, флуоресцентная спектроскопия. 


\section{Introduction}

The development of new fluorescent probes compounds that change the fluorescence when they are attached by a specific molecule - makes it possible to study in detail the chemical composition of living cells and even organisms, and its change in time and space. ${ }^{[1,2]}$ Analytical methods based on fluorescence are widely used in clinical chemistry and molecular diagnostics. In particular, sensitive methods for rapid analysis of steroid hormones, porphyrins, catecholamines and metabolites of drugs and other diagnostically important chemicals in the urine and blood plasma have been developed and introduced. ${ }^{[3]}$ The methods of fluorescent diagnostics in vivo are actively developed. ${ }^{[4,5]}$ In particular, the fluorescent probes have been created that selectively stained malignant tumors and help identify them during endoscopic diagnostic procedure or tomography. ${ }^{[6]}$ Thus, the creation of fluorescent sensors is an actual problem of organic chemistry, as they are widely used in analytical chemistry, clinical biochemistry, medicine, environmental protection, in various applications of biological and biomedical research. ${ }^{[7]}$

Thiacalixarenes are favorable building platform for the construction of such systems because of their unique three-dimensional structure as well as simplicity of functionalization of the macrocyclic platform ${ }^{[8-19]}$ and possibility of existence of different conformational isomers (cone, partial cone, 1,2-alternate, and 1,3-alternate).

1-Amidoanthraquinone fragment contains a polar $\mathrm{NH}$ group and a fluorophore moiety necessary for the detection of complex formation using fluorescence spectroscopy. The interaction of the carbonyl group of (ethoxycarbonyl) methoxy fragment $\left(-\mathrm{OCH}_{2} \mathrm{C}(\mathrm{O}) \mathrm{OEt}\right)$ with alkali metal cations allows to realize the template effect in the synthesis of thiacalixarene stereoisomers. It is also well known that this fragment is used in macrocyclic compounds for creation of effective receptors of the metal cations. ${ }^{[20]}$ Therefore, sequential functionalization of the lower rim of $p$-tertbutylthiacalix[4]arene by (ethoxycarbonyl)methoxy and fluorescent 1-amidoanthraquinone fragments was considered to be interesting for the design of fluorescent sensors. Also, synthesis of tetrasubstituted derivatives in three conformations cone, partial cone, 1,3-alternate, as potential fluorescent sensors was the aim of this work.

\section{Experimental}

\section{General}

${ }^{1} \mathrm{H}$ NMR spectra were recorded on $300 \mathrm{MHz}$ Varian XL-300 spectrometer, ${ }^{13} \mathrm{C}$ and $2 \mathrm{D}$ NOESY ${ }^{1} \mathrm{H}-{ }^{1} \mathrm{H}$ NMR spectra - on Bruker Avance II instrument with $125 \mathrm{MHz}$ and $500 \mathrm{MHz}$ respectively. Chemical shifts were determined relatively to the signals of residual protons of deuterated solvent $\left(\mathrm{CDCl}_{3}\right)$. The concentration of sample solutions was $3-5 \%$.

IR spectra (nujol) were recorded with Tensor 27 (Bruker) Fourier spectrometer.

Mass spectra were recorded with MALDI-TOF Dynamo Finnigan. 5-Nitroquinolin-8-ol was used as the matrix.

Melting points were determined using the Boetius Block apparatus.
Elemental analysis was performed with Perkin-Elmer 2400 Series II instruments.

Fluorescence spectra were recorded on a Fluorolog 3 luminescent spectrometer (Horiba Jobin Yvon). The excitation wavelengths were selected as $410 \mathrm{~nm}$, the emission scan range was $430-700 \mathrm{~nm}$. Excitation and emission slits were chosen as $6 \mathrm{~nm}$. Quartz cuvettes with optical path length of $10 \mathrm{~mm}$ were used. Correcting of emission spectra was carried out automatically (by "Fluoressence" program). A solutions of thiacalix[4]arenes 2-4 with $C=2.5 \cdot 10^{-5} \mathrm{M}$ concentration were prepared. The experiment was carried out at $25^{\circ} \mathrm{C}$.

5,11,17,23-Tetra-tert-butyl-25,27-dihydroxy-26,28di[(ethoxycarbonyl)methoxy]-2,8,14,20-tetrathiacalix[4]arene (1) was synthesized as previously described procedure ${ }^{[20]}, \mathrm{mp} 269^{\circ} \mathrm{C}$.

5,11,17,23-Tetra-tert-butyl-25,27-di[(ethoxycarbonyl) methoxy]-26,28-bis[N-(9',10'-dioxo-9',10'-dihydroanthracene-1'-yl)-aminocarbonylmethoxy]-2,8,14,20-tetrathiacalix [4] arene (cone-2). The mixture of 5,11,17,23-tetra-tert-butyl-25,27-dihydroxy-26,28-di[(ethoxycarbonyl)methoxy]-2,8,14,20-tetrathiacalix[4]arene (1) $(0.90 \mathrm{~g}, 1.01 \mathrm{mmol})$, an anhydrous sodium carbonate $(0.43 \mathrm{~g}, 4.04 \mathrm{mmol})$ and 2-bromo- $N$-(9',10'-dioxo-9',10'-dihydroanthracene-1'-yl)acetamide $(1.39 \mathrm{~g}, 4.04 \mathrm{mmol})$ in $60 \mathrm{ml}$ of dry acetone was refluxed for 60 hours. After cooling, the solid residue from the reaction mixture was removed by filtration, dissolved in chloroform and washed with distilled water. The organic layer was dried over molecular sieves, filtered and evaporated under reduced pressure. Crystallization of the resulting orange solid from ethanolchloroform mixture gave pure tetrasubstituted derivative $\mathbf{2}$ in cone conformation (the yield was calculated based on recovered initial compound 1). The filtrate of reaction mixture was evaporated under reduced pressure. The residue was washed with $20 \mathrm{ml}$ of ethanol and initial thiacalixarene $\mathbf{1}$ was formed, which was dried in vacuo over $\mathrm{P}_{2} \mathrm{O}_{5}$, in $0.30 \mathrm{~g}$ weight. The yield of product 2 is $0.54 \mathrm{~g}(57 \%)$. Mp: $239^{\circ} \mathrm{C} .{ }^{1} \mathrm{H}$ NMR $\left(\mathrm{CDCl}_{3}\right) \delta \mathrm{ppm}: 1.08\left(\mathrm{~s}, 18 \mathrm{H},\left(\mathrm{CH}_{3}\right)_{3} \mathrm{C}\right), 1.13$ $\left(\mathrm{s}, 18 \mathrm{H},\left(\mathrm{CH}_{3}\right)_{3} \mathrm{C}\right), 1.01\left(\mathrm{t}, 6 \mathrm{H},-\mathrm{O}-\mathrm{CH}_{2}-\mathrm{CH}_{3},{ }^{3} \mathrm{~J}_{\mathrm{HH}}=7.3 \mathrm{~Hz}\right), 3.90$ (q, $\left.4 \mathrm{H},-\mathrm{O}-\mathrm{CH}_{2}-\mathrm{CH}_{3},{ }^{3} \mathrm{~J}_{\mathrm{HH}}=7.3 \mathrm{~Hz}\right), 5.39$ (s, $\left.4 \mathrm{H},-\mathrm{O}-\mathrm{CH}_{2}-\mathrm{COOEt}\right), 4.46$ (s, 4H, -O-CH - $(\mathrm{O})-\mathrm{NH}), 7.27$ (s, 4H, Ar-H), 7.41 (s, 4H, Ar-H), 7.70-9.11 (m, 14H, Ar'-H), 12.69 (s, 2H, NH). ${ }^{13} \mathrm{C} \mathrm{NMR}\left(\mathrm{CDCl}_{3}\right)$ $\delta$ ppm: 29.70; 30.41; 30.80; 34.03; 34.51; 70.56; 70.81; 118.02; $119.41 ; 122.86 ; 125.07 ; 126.16 ; 127.16 ; 127.45 ; 128.61 ; 130.31$; $132.42 ; 132.82 ; 133.98 ; 134.53 ; 135.60 ; 141.49 ; 142.98 ; 143.96$; $147.98 ; 149.15 ; 155.66 ; 156.10 ; 166.87 ; 167.49 ; 182.64 ; 186.82$. ${ }^{1} \mathrm{H}-{ }^{1} \mathrm{H}$ NOESY spectrum (most important cross-peaks are presented): $\mathrm{H}^{19} / \mathrm{H}^{10^{\prime}}, \mathrm{H}^{9^{\prime}} / \mathrm{H}^{7^{\prime}}, \mathrm{H}^{7} / \mathrm{H}^{7}, \mathrm{H}^{4 b} / \mathrm{H}^{3}, \mathrm{H}^{4} \mathrm{~b} / \mathrm{H}^{3}, \mathrm{H}^{3} / \mathrm{H}^{5^{\prime}}$. IR (Nujol) $v \mathrm{~cm}^{-1}$ : 3070, $3236(\mathrm{NH}) ; 1729(\mathrm{C}(\mathrm{O}) \mathrm{OEt}) ; 1674,1579(\mathrm{C}(\mathrm{O})-\mathrm{NH})$. MS (MALDI-TOF): calculated $\left[\mathrm{M}^{+}\right] m / z=1418.4$, found $[\mathrm{M}+\mathrm{H}]^{+}$ $m / z=1419.6,[\mathrm{M}+\mathrm{Na}]^{+} m / z=1441.7,[\mathrm{M}+\mathrm{K}]^{+} m / z=1457.7$. El. Anal. Calcd for $\mathrm{C}_{80} \mathrm{H}_{78} \mathrm{~N}_{2} \mathrm{O}_{14} \mathrm{~S}_{4}(\%)$ : C, 67.68; H, 5.54; N, 1.97; S, 9.03. Found (\%): C, 67.45; H, 6.09; N, 1.49; S, 8.90.

5,11,17,23-Tetra-tert-butyl-25,27-di[(ethoxycarbonyl) methoxy $]-26,28$-bis $\left[N-\left(9^{\prime}, 10\right.\right.$ '-dioxo-9',10'-dihydroanthracene1'-yl)-aminocarbonylmethoxy]-2,8,14,20-tetrathiacalix[4]arene (partial cone-3). The mixture of 5,11,17,23-tetra-tert-butyl25,27-dihydroxy-26,28-di[(ethoxycarbonyl)methoxy]-2,8,14,20tetrathiacalix[4]arene (1) $(0.90 \mathrm{~g}, 1.01 \mathrm{mmol})$, an anhydrous potassium carbonate $(0.56 \mathrm{~g}, 4.04 \mathrm{mmol})$ and 2-bromo- $N$ (9',10'-dioxo-9',10'-dihydroanthracene-1'-yl)acetamide (1.39 g, $4.04 \mathrm{mmol}$ ) in $60 \mathrm{ml}$ of dry acetone was refluxed for 25 hours. After cooling, the solid residue from the reaction mixture was removed by filtration, dissolved in chloroform and washed with distilled water. The organic layer was dried over molecular sieves, filtered and evaporated under reduced pressure. Crystallization of the resulting orange solid from methanol-chloroform mixture gave pure tetrasubstituted derivative 2 in cone conformation in $0.35 \mathrm{~g}$ $(28 \%)$ weight. Mp: $239{ }^{\circ} \mathrm{C}$. The filtrate of reaction mixture was evaporated under reduced pressure. The residue was washed with $20 \mathrm{ml}$ of ethanol and the solid was formed, which was recrystallized from methanol-chloroform mixture. Thiacalix[4]arene $\mathbf{3}$ in partial 
cone conformation was obtained. Yield $0.50 \mathrm{~g}$ (35 \%). Mp: $142{ }^{\circ} \mathrm{C} .{ }^{1} \mathrm{H}$ NMR $\left(\mathrm{CDCl}_{3}\right) \delta \mathrm{ppm}: 1.03\left(\mathrm{~s}, 18 \mathrm{H},\left(\mathrm{CH}_{3}\right)_{3} \mathrm{C}\right), 1.27$ $\left(\mathrm{s}, 9 \mathrm{H},\left(\mathrm{CH}_{3}\right)_{3} \mathrm{C}\right), 1.42\left(\mathrm{~s}, 9 \mathrm{H},\left(\mathrm{CH}_{3}\right)_{3} \mathrm{C}\right), 1.15\left(\mathrm{t}, 6 \mathrm{H},-\mathrm{O}-\mathrm{CH}_{2}-\right.$ $\left.\mathrm{CH}_{3},{ }^{3} \mathrm{~J}_{\mathrm{HH}}=7.3 \mathrm{~Hz}\right), 4.03\left(\mathrm{~s}, 2 \mathrm{H},-\mathrm{O}-\mathrm{CH}_{2}-\mathrm{C}(\mathrm{O})-\mathrm{NH}\right), 4.06(\mathrm{q}, 4 \mathrm{H}$, $\left.-\mathrm{O}-\mathrm{CH}_{2}-\mathrm{CH}_{3},{ }^{3} \mathrm{HH}_{\mathrm{HH}}=7.3 \mathrm{~Hz}\right), 4.97\left(\mathrm{~s}, 2 \mathrm{H},-\mathrm{O}-\mathrm{CH}_{2}-\mathrm{C}(\mathrm{O})-\mathrm{NH}\right), 5.02$ (AB system, $\left.4 \mathrm{H},-\mathrm{O}-\mathrm{CH}_{2}-\mathrm{COOEt},{ }^{2} J_{\mathrm{HH}}=15.6 \mathrm{~Hz}\right), 7.25(\mathrm{~d}$ of $\mathrm{AB}$ system, $2 \mathrm{H}, \mathrm{Ar}-\mathrm{H}_{\mathrm{A}},{ }^{4} \mathrm{~J}_{\mathrm{HH}}=2.6 \mathrm{~Hz}$ ), $7.53\left(\mathrm{~d}\right.$ of AB system, $2 \mathrm{H}, \mathrm{Ar}-\mathrm{H}_{\mathrm{B}}$, $\left.{ }^{4} J_{\mathrm{HH}}=2.6 \mathrm{~Hz}\right), 7.55(\mathrm{~s}, 2 \mathrm{H}, \mathrm{Ar}-\mathrm{H}), 7.97(\mathrm{~s}, 2 \mathrm{H}, \mathrm{Ar}-\mathrm{H}), 7.64-9.17(\mathrm{~m}$, $14 \mathrm{H}, \mathrm{Ar}$ '-H), 12.34 (s, 1H, NH), $12.72(\mathrm{~s}, 1 \mathrm{H}, \mathrm{NH}) .{ }^{1} \mathrm{H}-{ }^{-1} \mathrm{H}$ NOESY spectrum (most important cross-peaks are presented): $\mathrm{H}^{3} / \mathrm{H}^{4 b}, \mathrm{H}^{3^{\prime}}$ / $\mathrm{H}^{4^{\prime} \mathrm{b}}, \mathrm{H}^{3+} / \mathrm{H}^{4+\mathrm{b}}, \mathrm{H}^{3^{\prime}} / \mathrm{H}^{5}, \mathrm{H}^{7+} / \mathrm{H}^{5}, \mathrm{H}^{11+} / \mathrm{H}^{5^{\prime}}, \mathrm{H}^{12+} / \mathrm{H}^{5^{\prime}}, \mathrm{H}^{13+} / \mathrm{H}^{5^{\prime}}, \mathrm{H}^{7^{\prime}} / \mathrm{H}^{9^{\prime}}$, $\mathrm{H}^{9^{\prime}} / \mathrm{H}^{4+\mathrm{b}}, \mathrm{H}^{7+} / \mathrm{H}^{4^{\prime} \mathrm{b}}$. IR (Nujol) $v \mathrm{~cm}^{-1}$ : 3329, $3205(\mathrm{NH}), 1736(\mathrm{C}(\mathrm{O})$ OEt); 1646, 1594 (C(O)-NH), 1675 (C(O)-NH). MS (MALDITOF): calculated $\left[\mathrm{M}^{+}\right] m / z=1418.4$, found $[\mathrm{M}+\mathrm{Na}]^{+} m / z=1441.5$, $[\mathrm{M}+\mathrm{K}]^{+} m / z=1457.5$. El. Anal. Calcd for $\mathrm{C}_{80} \mathrm{H}_{78} \mathrm{~N}_{2} \mathrm{O}_{14} \mathrm{~S}_{4}(\%)$ : C, 67.68; H, 5.54; N, 1.97; S, 9.03. Found (\%): C, 67.49; H, 5.44; N, $2.21 ; \mathrm{S}, 9.19$

5,11,17,23-Tetra-tert-butyl-25,27-di[(ethoxycarbonyl) methoxy $]-26,28$-bis [N-(9',10'-dioxo-9',10'-dihydroanthracene1 '-yl)-aminocarbonylmethoxy]-2,8,14,20-tetrathiacalix [4] arene (1,3-alternate-4). The mixture of 5,11,17,23-tetra-tert-butyl25,27-dihydroxy-26,28-di[(ethoxycarbonyl)methoxy]-2,8,14,20tetrathiacalix[4]arene (1) (1.00 g, $1.12 \mathrm{mmol})$, an anhydrous cesium carbonate (1.46 g, $4.48 \mathrm{mmol})$ and 2-bromo- $N$-(9',10'-dioxo9',10'-dihydroanthracene-1'-yl)acetamide (1.54 g, $4.48 \mathrm{mmol})$ in $60 \mathrm{ml}$ of dry acetone was refluxed for 12 hours. After cooling, the solid residue from the reaction mixture was removed by filtration, dissolved in chloroform and washed with distilled water. The organic layer was dried over molecular sieves, filtered and evaporated under reduced pressure. Crystallization of the resulting brown solid from methanol-chloroform mixture gave pure tetrasubstituted at the lower rim thiacalix[4]arene 4 in 1,3-alternate conformation. The filtrate of reaction mixture was evaporated under reduced pressure. As the result difficult separable mixture of alkylating agent and products of indirect reactions were isolated. The yield of 4 is $0.90 \mathrm{~g}(56 \%)$. Mp: $249{ }^{\circ} \mathrm{C} .{ }^{1} \mathrm{H}$ NMR $\left(\mathrm{CDCl}_{3}\right) \delta \mathrm{ppm}: 1.07$ $\left(\mathrm{s}, 18 \mathrm{H},\left(\mathrm{CH}_{3}\right)_{3} \mathrm{C}\right), 1.28\left(\mathrm{~s}, 18 \mathrm{H},\left(\mathrm{CH}_{3}\right)_{3} \mathrm{C}\right), 1.24\left(\mathrm{t}, 6 \mathrm{H},-\mathrm{O}-\mathrm{CH}_{2}-\right.$ $\left.\mathrm{CH}_{3},{ }^{3} J_{\mathrm{HH}}=7.3 \mathrm{~Hz}\right), 3.91\left(\mathrm{~s}, 4 \mathrm{H},-\mathrm{O}-\mathrm{CH}_{2}-\right), 4.19$ (q, 4H, -O- $\mathrm{CH}_{2}-\mathrm{CH}_{3}$, $\left.{ }^{3} J_{\mathrm{HH}}=7.3 \mathrm{~Hz}\right), 4.67\left(\mathrm{~s}, 4 \mathrm{H},-\mathrm{O}-\mathrm{CH}_{2}-\right), 7.43(\mathrm{~s}, 4 \mathrm{H}, \mathrm{Ar}-\mathrm{H}), 7.62(\mathrm{~s}, 4 \mathrm{H}$, Ar-H), 7.66-9.19 (m, 14H, Ar'-H), 12.53 (s, 2H, NH). ${ }^{13} \mathrm{C}$ NMR $\left(\mathrm{CDCl}_{3}\right) \delta$ ppm: $14.13 ; 30.89 ; 31.04 ; 34.16 ; 34.22 ; 60.63 ; 66.83$; $118.51 ; 122.54 ; 126.83 ; 126.89 ; 127.19 ; 127.60 ; 129.43 ; 130.27$; $132.80 ; 133.98 ; 134.04 ; 134.17 ; 134.21 ; 135.14 ; 146.24 ; 147.44$; $155.37 ; 167.99 ; 168.07 ; 182.94 ; 186.14 .{ }^{1} \mathrm{H}-{ }^{1} \mathrm{H}$ NOESY spectrum (most important cross-peaks are presented): $\mathrm{H}^{5} / \mathrm{H}^{4 \mathrm{~b}}, \mathrm{H}^{5} / \mathrm{H}^{4 \mathrm{~b}}, \mathrm{H}^{4 \mathrm{~b}} /$ $\mathrm{H}^{7^{\prime}}, \mathrm{H}^{4} \mathrm{~b} / \mathrm{H}^{7}, \mathrm{H}^{4 \mathrm{~b}} / \mathrm{H}^{9}, \mathrm{H}^{9^{\prime}} / \mathrm{H}^{10^{\prime}}, \mathrm{H}^{4} \mathrm{~b} / \mathrm{H}^{20}, \mathrm{H}^{7} / \mathrm{H}^{5^{\prime}}, \mathrm{H}^{7^{7}} / \mathrm{H}^{3}, \mathrm{H}^{11} / \mathrm{H}^{12}, \mathrm{H}^{12} /$ $\mathrm{H}^{13}, \mathrm{H}^{17} / \mathrm{H}^{18}, \mathrm{H}^{18} / \mathrm{H}^{19}, \mathrm{H}^{19} / \mathrm{H}^{20}$. IR (Nujol) $v \mathrm{~cm}^{-1}$ : 3327, $3192(\mathrm{NH})$, 1730 (C(O)OEt); 1649, 1578 (C(O)-NH), 1670 (C(O)-NH). MS (MALDI-TOF): calculated $\left[\mathrm{M}^{+}\right] \mathrm{m} / z=1418.4$, found $[\mathrm{M}+\mathrm{Na}]^{+} \mathrm{m} /$ $z=1441.4$. El. Anal. Calcd for $\mathrm{C}_{80} \mathrm{H}_{78} \mathrm{~N}_{2} \mathrm{O}_{14} \mathrm{~S}_{4}(\%)$ : C, 67.68; H, 5.54; N, 1.97; S, 9.03. Found (\%): C, 67.24; H, 5.52; N, 2.00; S, 9.43.

\section{Results and Discussion}

\section{Synthesis}

The obtaining of differently substituted at the lower rim derivatives in the case of thia analogue of calix[4]arene is challenging, because it requires comprehensive selection of the reaction conditions (ratio of reactants, temperature, and synthesis duration) ${ }^{[21,22]}$

Due to the successful selective 1,3-dialkylation of the lower rim of $p$-tert-butylthiacalix[4]arene by ethyl bromoacetate ${ }^{[20]}$ to create differently substituted synthetic receptors the interest was further functionalization of the macrocycle 1 by $N$ - $\left(9^{\prime}, 10^{\prime}\right.$-dioxo-9', 10'-dihydroanthracene1 '-yl)acetamide fragment containing the polar $\mathrm{NH}$ group. It is known that this fragment used in the so-called OFF-ON photoswitchable receptors that allow to prepare fluorescent sensors based on it. ${ }^{[23]}$

In this regard, it was proposed to introduce in thiacalixarene 1 substituents containing 1-amidoanthraquinone fragment by alkylation of the free phenolic hydroxyls and see whether the template effect of alkali metal is realized in the synthesis of different stereoisomers.

The interaction of macrocycle 1 with 2-bromo- $N-\left(9^{\prime}, 10^{\prime}\right.$ dioxo-9',10'-dihydroanthracene-1'-yl)acetamide in the presence of metal carbonates $\left(\mathrm{M}_{2} \mathrm{CO}_{3}, \mathrm{M}=\mathrm{Na}, \mathrm{K}, \mathrm{Cs}\right)$ in acetone was studied. From the reaction mixtures three stereoisomers of tetrasubstituted at the lower rim $p$-tert-butylthiacalix[4]arene in the conformations of cone $\mathbf{2}$, partial cone $\mathbf{3}$ and 1,3-alternate 4 were isolated. It should be noted that depending on the nature of the alkali metal cation (sodium, potassium or cesium carbonate) in the alkylation of diester 1 by 2 -bromo- $N-\left(9^{\prime}, 10^{\prime}-\right.$ dioxo-9', 10'-dihydroanthracene-1'-yl)acetamide the template effect of metal cation is observed. Thus, using a sodium carbonate tetrasubstituted product $\mathbf{2}$ in cone conformation, using a potassium carbonate - a mixture of tetrasubstituted stereoisomers $\mathbf{2}$ and $\mathbf{3}$ in conformations cone and partial cone, respectively, and using cesium carbonate - stereoisomer 4 in 1,3-alternate conformation are formed (Scheme 1).

The obtained compounds 2-4 were characterized by NMR ${ }^{1} \mathrm{H},{ }^{13} \mathrm{C}, 2 \mathrm{D}$ NOESY, IR spectroscopy, mass spectrometry (MALDI-TOF), and their composition was confirmed by elemental analysis.

In the ${ }^{1} \mathrm{H}$ NMR spectrum of the macrocycle 4 (Figure 1) there are two singlets of protons of tert-butyl groups at 1.07 and $1.28 \mathrm{ppm}$ with equal integral intensities, two singlets of protons of oxymethylene groups (-O- $\left.\mathrm{CH}_{2}-\right)$ in the area of 3.91 and $4.67 \mathrm{ppm}$, two singlets of aromatic protons at 7.43 and $7.62 \mathrm{ppm}$ and a singlet of amide protons $(\mathrm{NH})$ at $12.53 \mathrm{ppm}$ are observed. The signals of methylene protons of the ester group appear as a quartet at $4.19 \mathrm{ppm}$. The signals of protons of anthraquinone fragment are observed in ${ }^{1} \mathrm{H}$ NMR spectrum of compound 4 as a multiplet at 7.66-9.19 ppm area.

The spatial structure of compounds 2-4 was studied by two-dimensional NMR ${ }^{1} \mathrm{H}-{ }^{1} \mathrm{H}$ NOESY spectroscopy. The presence of cross-peaks due to dipole-dipole interaction of the protons of the methyl group of the ester moiety with protons of 1-amidoanthraquinone fragment, as well as crosspeaks between the aromatic protons of the macrocycle, and cross-peaks between oxymethylene protons of different substituents in 2D NMR NOESY spectrum of compound 2 (Figure 2) confirms that macrocycle $\mathbf{2}$ is in a cone conformation.

It should be noted that in the IR spectra of the obtained compounds 2-4 absorption band of valence vibrations of the amide group $\left(v, 3192-3329 \mathrm{~cm}^{-1}\right)$ appears but valence vibrations of hydroxyl groups are absent, indicating about complete substitution of the initial thiacalix[4]arene at the lower rim (Table 1).

Thus, as a result of the conducted researches the realization of the template effect of the alkali metal cation during the functionalization of diester of p-tertbutylthiacalix[4] arene by 2-bromo- $N-\left(9^{\prime}, 10^{\prime}\right.$-dioxo-9', $10^{\prime}$ dihydroanthracene-1'-yl)acetamide was shown. 


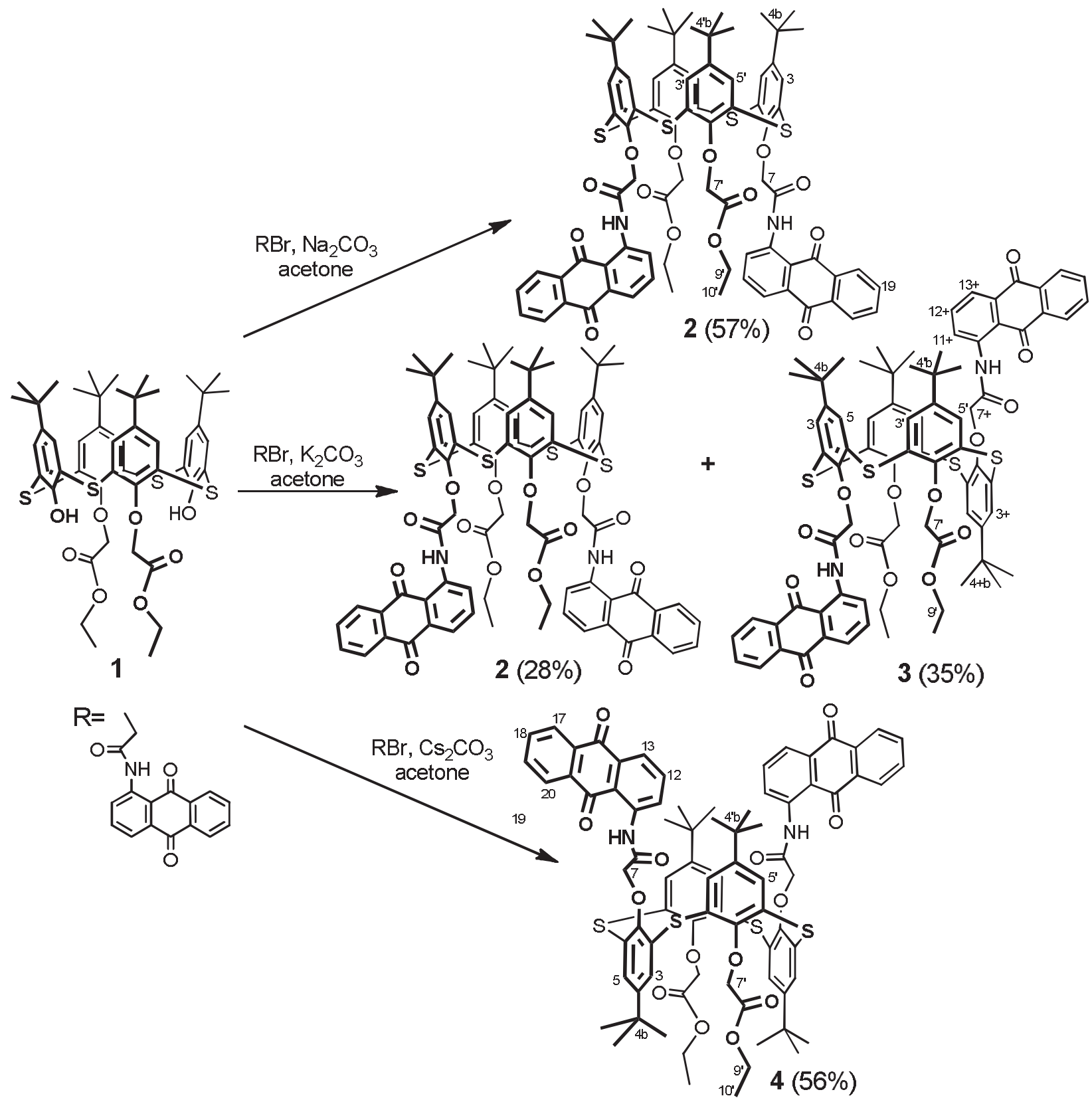

Scheme 1. Synthesis of compounds 2-4.

Table 1. The IR spectra data of thiacalix[4]arenes 2-4 $\left(v, \mathrm{~cm}^{-1}\right)$.

\begin{tabular}{cccc}
\hline Groups & $\mathbf{2}$ & $\mathbf{3}$ & $\mathbf{4}$ \\
\hline \multirow{2}{*}{-NH } & 3236, & 3329, & 3327, \\
& 3070 & 3205 & 3192 \\
& & & 1649, \\
$-\mathrm{C}(\mathrm{O})-\mathrm{N}-$ & 1650, & 1646, & 1578 \\
$-\mathrm{C}(\mathrm{O})-\mathrm{NH}-$ & 1579 & 1594 & 1670 \\
$-\mathrm{C}(\mathrm{O}) \mathrm{OEt}$ & 1674 & 1675 & 1730 \\
\hline
\end{tabular}

\section{Study of Fluorescence Properties}

The anthraquinone fragments are well known as fluorophores capable of the excited state intramolecular proton transfer (ESIPT) (Figure 3, A) ${ }^{[24]}$ which makes them promising compounds for creation of different chemosensors based on them.

The study of the electronic absorption spectra of the compounds obtained showed their similarity to those of the compounds in cone and 1,3-alternate conformations, but significant difference from those in partial cone conformation (Figure 4). The spectra of all the compounds have a low intensity band at longer wavelengths related to the $n \rightarrow \pi^{*}$ transition of the anthraquinone fragment (410 nm for the compounds $\mathbf{2}$ and $\mathbf{4}$ and $370 \mathrm{~nm}$ for the compound $\mathbf{3}$ ).

The study of fluorescent properties of the compounds obtained showed that they have a marked green fluorescence (540-555 nm emission maxima) (Figure 5). The large Stokes shift reaching about $185 \mathrm{~nm}$ for the compound $\mathbf{3}$ in partial cone conformation is typical for all the compounds. Moreover, there are significant differences in the intensity and the form of their emission spectra. Thus, the most 


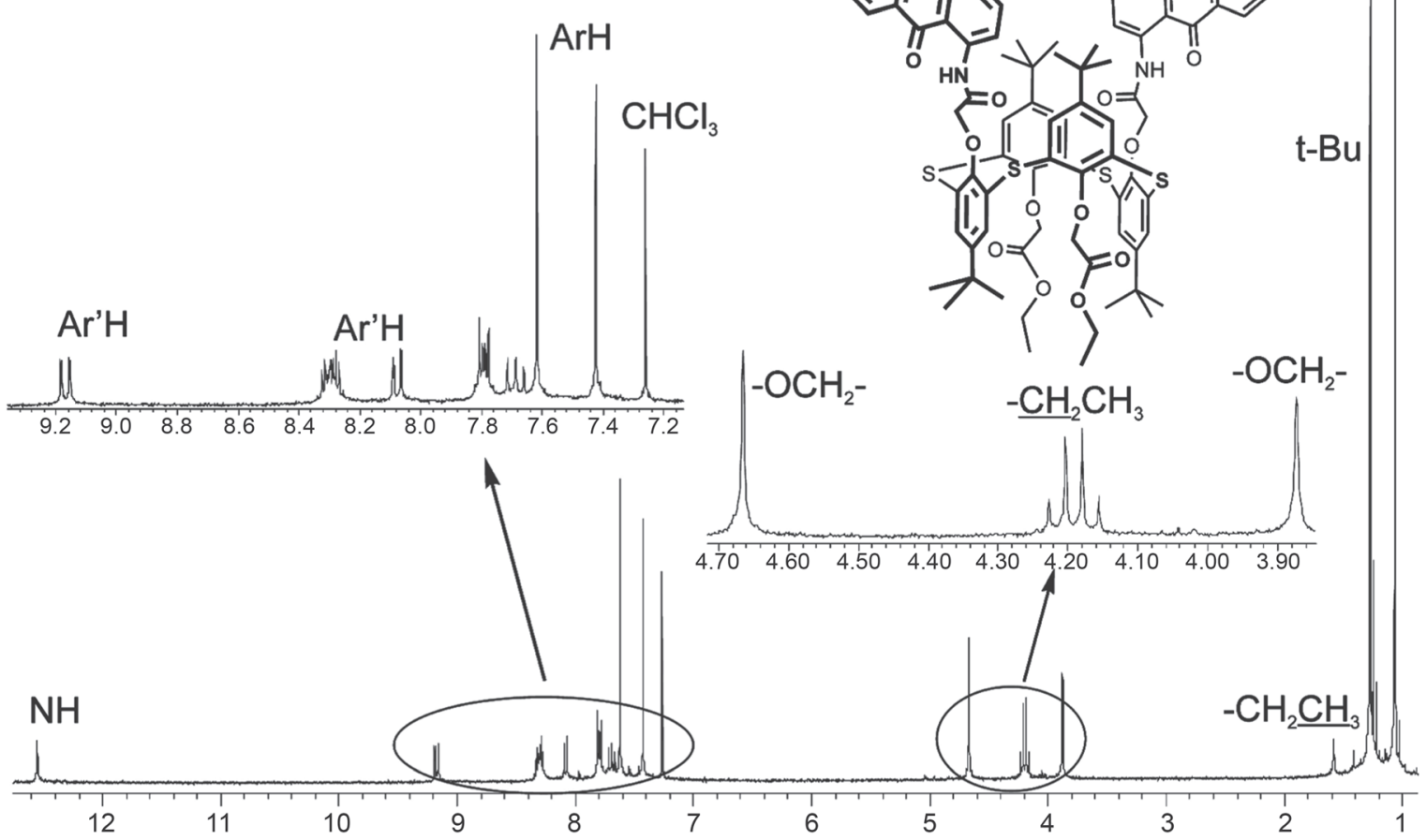

Figure 1. ${ }^{1} \mathrm{H}$ NMR spectrum of compound 4 (in $\mathrm{CDCl}_{3}, 25^{\circ} \mathrm{C}, 300 \mathrm{MHz}$ ).
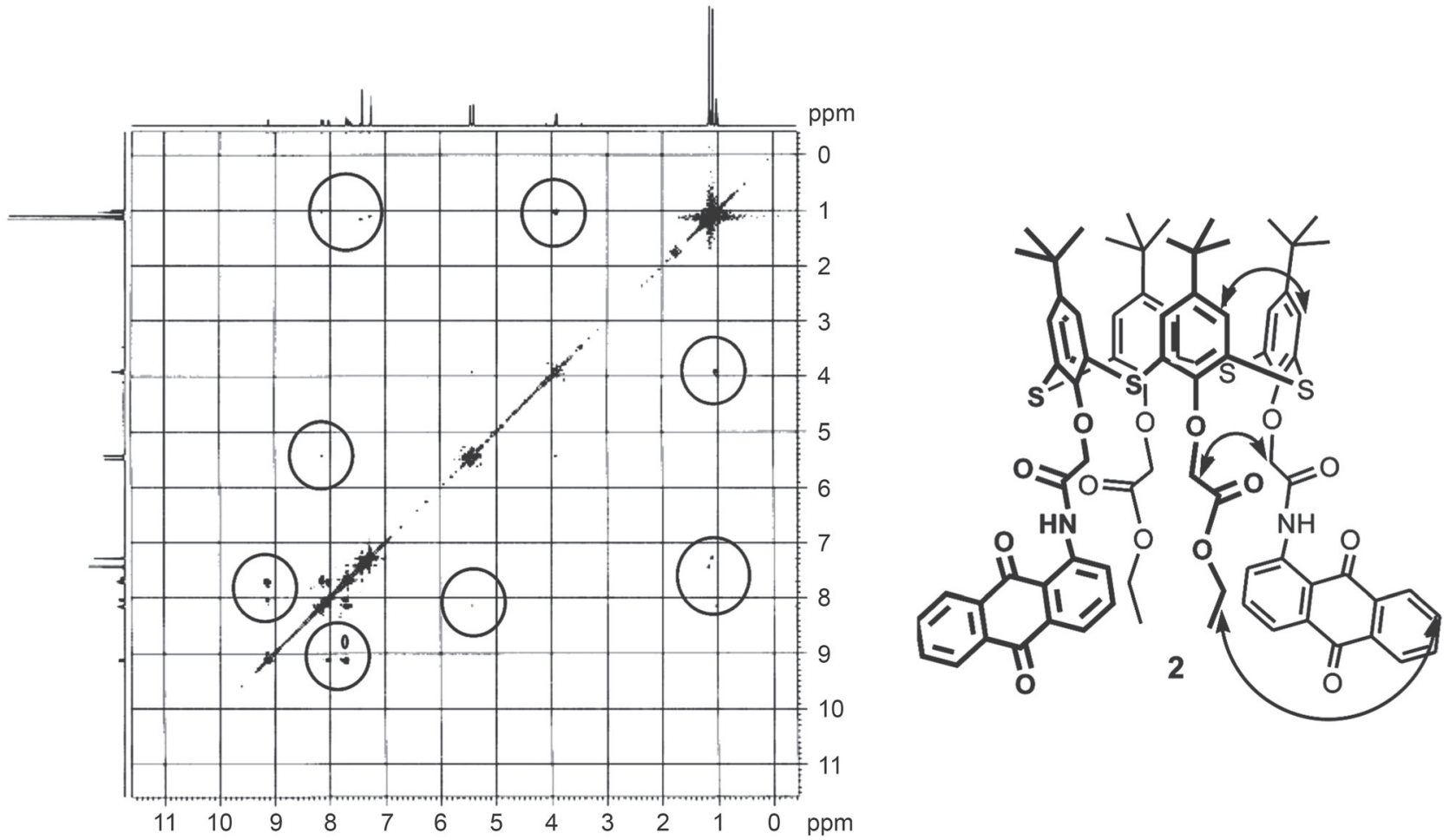

Figure 2. Two-dimensional NMR ${ }^{1} \mathrm{H}-{ }^{1} \mathrm{H}$ NOESY spectrum of compound 2 (in $\mathrm{CDCl}_{3}, 25{ }^{\circ} \mathrm{C}, 500 \mathrm{MHz}$ ). 
intense fluorescence has a compound $\mathbf{4}$ in 1,3-alternate conformation.

The compound $\mathbf{2}$ in a cone conformation has a similar spectrum, but it is significantly inferior in emission intensity (1.5-fold). The spectrum of the compound 3 in a partial cone conformation one can see not only loses in two previous emission intensities $(540,000 \mathrm{cps})$, but also different from them in the form (the absence of emission band in the "blue" region of $490 \mathrm{~nm}$ ). As is well known, during ESIPT a shift of the emission band to longer wavelengths (red shift) is observed..$^{[7]}$ We have previously shown ${ }^{[11]}$ that the introduction of proton-acceptor diethylamide groups leads to a significant increase in emission of spectra of a similar compounds as a result of ESIPT blockage.

As in compounds cone-2 and 1,3-alternate-4 fluorophore fragments located on the one side of the macrocyclic platform, they are capable of forming intramolecular excimers. ${ }^{[25]}$
As a result the probability of ESIPT realization reduced (Figure 3). Therefore the emission band in the blue region $(490 \mathrm{~nm})$ is appeared. In cone conformation of compound $\mathbf{2}$ on the one side of the macrocyclic platform both 1-amidoanthraquinone and (ethoxycarbonyl)methoxy fragments are situated. This ester fragment competes with carbonyl group of quinone fragment in formation of hydrogen bonds with amide proton resulted in decreasing of the probability of excimers formation (Figure 3, B). As a result, a decrease in the emission intensity of the emission spectrum of compound $\mathbf{2}$ in cone conformation, as compared with compound $\mathbf{4}$ in 1,3-alternate conformation because in this conformation intramolecular excimer formation nothing prevents (Figure 3, C).

The partial cone conformation does not allow formation of intramolecular excimer complex, resulting in the possibility of ESIPT remains high, so that there is practically<smiles>[R]N=C1C=CC=C2C(=O)c3ccccc3C(O[Hg])=C2C1=O</smiles>

Figure 3. The blockage of ESIPT in anthraquinone fragment as a result of intramolecular eximer formation.

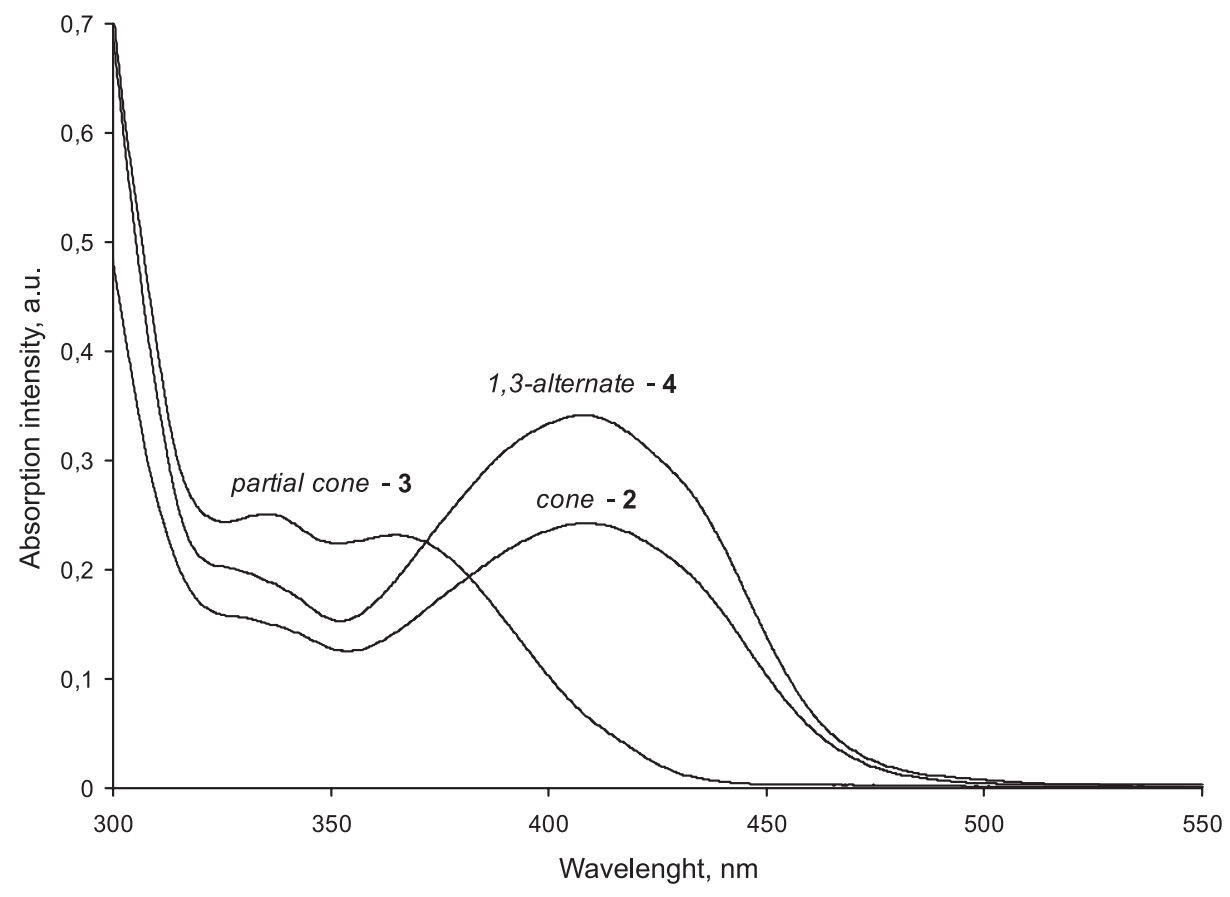

Figure 4. UV-Vis absorption spectra of compounds $2-4\left(2.5 \cdot 10^{-5} \mathrm{M}, 25^{\circ} \mathrm{C}\right)$ in chloroform. 


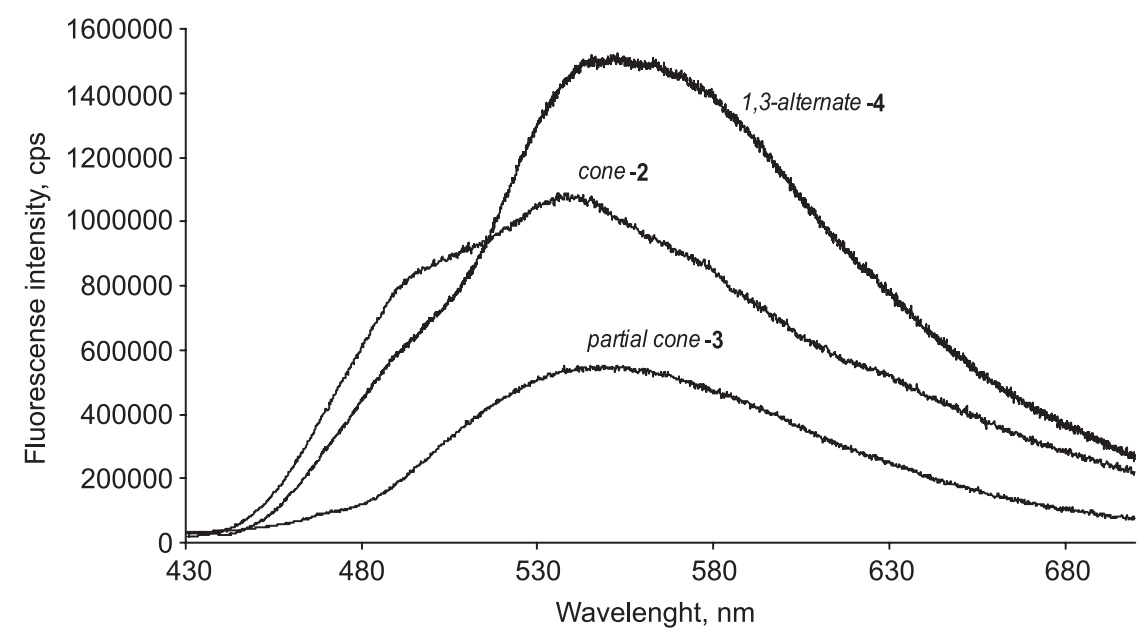

Figure 5. The emission spectra of compounds 2-4 $\left(2.5 \cdot 10^{-5} \mathrm{M}, 25^{\circ} \mathrm{C}\right)$ in chloroform.

no emission band in the shortwave region. The maximum emission of this conformer is most strongly bathochromic shifted $(555 \mathrm{~nm})$.

\section{Conclusion}

New tetrasubstituted at the lower rim thiacalix[4]arenes containing both 1-amidoanthraquinone and (ethoxycarbonyl)methoxy fragments in three conformations cone, partial cone and 1,3-alternate were synthesized. The structure of the compounds obtained was established by ${ }^{1} \mathrm{H} \mathrm{NMR},{ }^{13} \mathrm{C}$, IR spectroscopy, mass spectrometry (MALDI-TOF), and the composition was confirmed by elemental analysis. The fluorescent properties of the obtained compounds were studied. It was shown that depending of macrocyclic conformation the intensity and form of emission spectra are different.

Acknowledgements. This work was financial supported by Russian Science Foundation (grant № 16-13-00005).

\section{References}

1. Schepartz A., Gonzalez R.L. Curr. Opin. Chem. Biol. 2011, 15, 749-751.

2. Drummen G.P.C. Molecules 2012, 17, 14067-14090.

3. O'Haver T.C. J. Chem. Educ. 1978, 55, 423-428.

4. Rao J., Dragulescu-Andrasi A., Yao H. Curr. Opin. Biotechnol. 2007, 18, 17-25.

5. Hilderbrand S.A., Weissleder R. Curr. Opin. Chem. Biol. 2010, 14, 71-79.

6. Kobayashi H., Ogawa M., Alford R., Choyke P.L., Urano Y. Chem. Rev. 2010, 110, 2620-2640.

7. Lakowicz J.R. Principles of Fluorescence Spectroscopy. Springer US, 2006, $954 \mathrm{p}$.

8. Vavilova A.A., Mostovaya O.A., Nosov R.V., Yagarmina A.N., Stoikov I.I. Butlerov Commun. 2012, 29, 8-12.

9. Vavilova A.A., Meleshina M.V., Gorbachuk V.V., Yakimova L.S., Stoikov I.I. Butlerov Commun. 2012, 31, 18-24.
10. Vavilova A.A., Mostovaya O.A., Nosov R.V., Yagarmina A.N., Stoikov I.I. Butlerov Commun. 2012, 32, 1-7.

11. Vavilova A.A., Nosov R.V., Yagarmina A.N., Mostovaya O.A., Antipin I.S., Konovalov A.I., Stoikov I.I. Macroheterocycles 2012, 5, 396-403.

12. Vavilova A.A., Nosov R.V., Yakimova L.S., Antipin I.S., Stoikov I.I. Macroheterocycles 2013, 6, 219-226.

13. Puplampu J.B., Yakimova L.S., Vavilova A.A., Rizvanov I.Kh., Stoikov I.I. Macroheterocycles 2015, 8, 75-80.

14. Puplampu J.B., Yakimova L.S., Vavilova A.A., Fayzullin D.A., Zuev Yu.F., Stoikov I.I. Macroheterocycles 2014, 7, 337-344.

15. Stoikov I.I., Mostovaya O.A., Yakimova L.S., Yantemirova A.A., Antipin I.S., Konovalov A.I. Mendeleev Commun. 2010, 20, 359-360.

16. Stoikov I.I., Yantemirova A.A., Nosov R.V., Rizvanov I.Kh., Julmetov A.R., Klochkov V.V., Antipin I.S., Konovalov A.I. and Zharov I. Org. Biomol. Chem. 2011, 9, 3225-3234.

17. Stoikov I.I., Yantemirova A.A., Nosov R.V., Julmetov A.R., Klochkov V.V., Antipin I.S., Konovalov A.I. Mendeleev Commun. 2011, 21, 41-43.

18. Stoikov I.I., Agafonova M.N., Yakimova L.S., Antipin I.S., Konovalov A.I. Molecular Recognition of Carboxylic Acids and Carboxylate Anions by Synthetic Receptor. In: Molecular Recognition: Biotechnology, Chemical Engineering and Materials Applications, Ch.1, Nova Science Publishers, 2011. p. $1-43$.

19. Yakimova L.S., PuplampuJ.B., Vavilova A.A., Stoikov I.I. Polyammonium Derivatives of (Thia)calix[4]arene: Synthesis and Interaction with Nucleic Acids. In: Advances in Chemistry Research, Vol. 28, Ch. 4, Nova Science Publishers, 2015. p. 145-169.

20. Iki N., Morohashi N., Narumi F., Fujimoto T., Suzuki T., Miyano S. Tetrahedron Lett. 1999, 40, 7337-7341.

21. Lhotak P. Eur. J. Org. Chem. 2004, 1675-1692.

22. Morohashi N., Narumi F., Iki N., Hattori T., Miyano S. Chem. Rev. 2006, 106, 5291-5316.

23. Jung H.S., Kim H.J., Vicens J., Kim J.S. Tetrahedron Lett. 2009, 50, 983-987.

24. Han D.Y., Kim J.M., Kim J., Jung H.S., Lee Y.H., Zhang J.F., Kim J.S. Tetrahedron Lett. 2010, 51, 1947-1951.

25. Stoikov I.I., Sitdikov R.R., Mostovaya O.A. Russ. J. Org. Chem. 2014, 50, 581-588. 